J. Dairy Sci. 99:8053-8069

http://dx.doi.org/10.3168/jds.2015-10323

(C) 2016, THE AUTHORS. Published by FASS and Elsevier Inc. on behalf

of the American Dairy Science Association ${ }^{\circledR}$. This is an open access article under

the CC BY-NC-ND license (http://creativecommons.org/licenses/by-nc-nd/3.0/).

\title{
Effects of air exposure, temperature and additives on fermentation characteristics, yeast count, aerobic stability and volatile organic compounds in corn silage
}

\author{
K. Weiss, ${ }^{* 1}$ B. Kroschewski, ${ }^{*}$ and H. Auerbach $†$ \\ ${ }^{*}$ Humboldt Universität zu Berlin, Albrecht Daniel Thaer-Institute of Agricultural and Horticultural Sciences, D-10115 Berlin, Germany \\ †International Silage Consultancy (ISC), D-06193 Wettin-Löbejün, Germany
}

\begin{abstract}
Ensiling conditions strongly influence fermentation characteristics, yeast count, and aerobic stability. Numerous volatile organic compounds including esters are produced, which may negatively affect feed intake and animal performance and air quality. In addition to a farm survey, 3 laboratory experiments were carried out to study the effects of air (by delayed sealing or by air infiltration during anaerobic storage), temperature (20 and $35^{\circ} \mathrm{C}$ ), and various types of additives [blends of either sodium benzoate and sodium propionate (SBSP) or of sodium benzoate and potassium sorbate (SBPS); buffered mixture of formic and propionic acids (FAPA); homofermentative inoculant (LAB)]. After additive treatment, chopped whole corn plants were packed into 1.5-L glass jars and stored for several months. For treatments with air infiltration, glass jars with holes in the lid and body were used. The farm survey in 2009 revealed large variation in lactate, acetate, ethanol, npropanol, and 1,2-propanediol concentrations. Whereas ethyl esters were detected in all silages, the mean ethyl lactate concentrations were higher than those for ethyl acetate (474 vs. $38 \mathrm{mg} / \mathrm{kg}$ of dry matter). In the ensiling experiments, few unequivocal effects of the tested factors on the analyzed parameters were observed due to many interactions. Delayed ensiling without additives decreased lactic acid production but, in one trial, increased acetic acid and had no effect on ethanol. The effect of delayed sealing on yeast counts and aerobic stability differed widely among experiments. Air infiltration during fermentation tested in one trial did not alter lactic acid production, but resulted in more acetic acid in delayed and more ethanol than in promptly sealed untreated silages. Greater ethanol production
\end{abstract}

Received August 28, 2015.

Accepted June 20, 2016

${ }^{1}$ Corresponding author: kirsten.weiss@agrar.hu-berlin.de was associated with increased yeast numbers. Storage at high temperature resulted in lower lactic acid and n-propanol, and a trend toward reduced ethanol production was observed. The additive FAPA consistently caused increased ethanol and reduced n-propanol levels with no effect on yeast counts and aerobic stability. When the additives SBSP and SBPS decreased npropanol and ethanol, reduced yeast counts were also found. Ethyl ester formation was strongly correlated with those of ethanol and to a lesser degree with those of the respective acid.

Key words: air ingress, storage temperature, silage additives, volatile organic compounds

\section{INTRODUCTION}

The occurrence of volatile organic compounds (VOC) in grass and corn silages was first reported more than 50 yr ago (Morgan and Pereira 1962), but has only recently attracted significant attention (Hafner et al., 2010, 2012; Howard et al., 2010; Malkina et al., 2011). Ethanol, and to a lesser extent aldehydes, can significantly contribute to air pollution by photochemical reactions with oxides of nitrogen (Howard et al., 2010). In their recent review, Hafner et al. (2013) associated the highest VOC emissions from corn and the resulting ozone formation to various alcohols. Other volatiles (e.g., aldehydes, esters, and acids) may also contribute significantly to emissions under some conditions. Anecdotal evidence has been provided from farmers in Germany (Weiss et al., 2009a), Denmark (Raun and Kristensen, 2010), and the United States (Richard Muck, US Dairy Forage Center, Madison, WI, personal communication) on negative effects of odd (atypically)-smelling corn silages on feed intake and performance by dairy cows. Based on the routinely measured indices of silage fermentation quality $-\mathrm{pH}$, ammonia-N, organic acids, and alcohols - this phenomenon cannot be explained. According to Weiss et al. (2009a), suspect corn silages of German origin were 
well compacted and well fermented, had low $\mathrm{pH}$ and yeast counts, and were stable upon exposure to air. As even high concentrations of added acetic acid (Daniel et al., 2013a) or ethanol (Randby et al., 1999; Daniel et al., 2013a,c) and increased acetic acid levels ( $\geq 4 \%$ of DM) by inoculation with heterofermentative inoculants do not appear to adversely affect feed intake (Ranjit et al., 2002; Kleinschmitt et al., 2013), other VOC (e.g., ethyl and propyl esters) may be considered to explain the observations on dairy farms.

Ethyl and propyl esters of lactate and acetate, respectively, have been found in farm silages and in numerous ensiling experiments with corn (Kristensen et al. 2010; Raun and Kristensen, 2010; Weiss and Auerbach, 2012a). However, the knowledge on the effects of specific esters on feed intake by ruminants is still very limited and conflicting. Krizsan et al. (2007) and Gerlach et al. (2013) overserved negative correlations between some VOC and feed intake, whereas Daniel et al. (2013c) reported no difference when fresh sugar cane silage was compared with oven-dried material, resulting in the loss of volatiles, which was reconstituted with water before feeding. Knowledge is still scarce as to the effects of ensiling conditions (e.g., delayed sealing and air infiltration during the ensiling process, storage temperature) and silage additive type on the formation of VOC, especially that of esters. In previous studies, air infiltration resulted in a decline of lactic acid concentration (Bolsen et al. 1993; Mills and Kung, 2002; Moshtaghi Nia and Wittenberg, 2000). Conflicting results were described on the effects of delayed sealing and air infiltration on acetic acid and production of VOC, especially ethanol (Moshtaghi Nia and Wittenberg, 2000; Mills and Kung, 2002; Kim and Adesogan, 2006). Kim and Adesogan (2006) observed lower lactate and acetate production in corn silage by storage at higher temperature, whereas Weinberg et al. (2001) found no effect of temperature on ethanol or acetate contents. Data on the effects of temperature on ester formation were not available.

Silage additives affect fermentation pattern and aerobic stability in different ways according to their specific mode of action (Kung et al., 2003). Hafner et al. (2014) and Savage et al. (2014) observed increased ethanol and ethyl acetate accumulation by the use of homofermentative lactic acid bacteria, whereas the application of heterofermentative lactic acid bacteria containing Lactobacillus buchneri in sorghum silages (Auerbach and Weiss, 2012) resulted in decreased concentrations of ethanol and its esters of lactic and acetic acids. Kristensen et al. (2010) found an increase in n-propanol and propyl acetate in corn silages treated with Lactobacillus buchneri. The application of sodium benzoate and potassium sorbate to corn and sorghum at ensiling, alone or in combination, has consistently reduced ethanol contents in silages (Weiss and Auerbach, 2012b; Bernardes et al., 2014; Da Silva et al., 2014). When reported, concentrations of ethyl esters have also been reduced (Auerbach and Weiss, 2012; Hafner et al., 2015; Weiss and Auerbach, 2012b). Interestingly, buffered acid mixtures, mainly containing formic and propionic acids, stimulated ethanol (Auerbach et al., 2012) and ethyl ester production in corn silage (Weiss and Auerbach, 2012b). However, which individual factors increase the production of VOC has not been thoroughly studied with particular focus on esters in corn silage and how they may interact. Therefore, the objective of our experiments was to evaluate the effects of air by delayed sealing or repeated air infiltration during the ensiling process, storage temperature, additive type, and their interactions on selected fermentation characteristics, yeast count, aerobic stability, and the formation of ethyl esters of lactate and acetate in corn silage. These ethyl esters were considered indicator substances for the total VOC production in corn silage (Weiss et al., 2009a) and can be determined by routine analytical procedures, such as GC. Different additive types were used to evaluate the effect of the additives on VOC formation and, more so, to induce large variations in the concentrations of fermentation end-products, which may play a role in esterification reactions.

\section{MATERIALS AND METHODS}

\section{Experimental Design of the Ensiling Experiments}

Farm Survey. Corn silage samples were taken from the freshly prepared face in the core sections of 11 bunker silos on dairy farms located in the German State of Brandenburg in 2009 using a hollow drill. All farms had reported problems with feed intake and performance by dairy cows. Silages had been made either without additives (4 silos) or treated with different types of commercially available inoculants ( 3 silos with pure homofermentative inoculants; 1 silo with pure heterofermentative inoculants; 3 silos with inoculants composed of homo- and heterofermentative lactic acid bacteria).

Laboratory Ensiling Experiments. A total of 3 laboratory ensiling experiments were carried out with corn, which was treated with various additives and subjected to different storage conditions with regard to temperature and air exposure (Table 1). In all experiments, a portion of the total forage mass was either immediately ensiled (prompt) or left loosely piled on a clean concrete floor in a barn at ambient temperature 
Table 1. Design of the ensiling experiments 1 to 3

\begin{tabular}{|c|c|c|c|}
\hline Description & Trial 1 & Trial 2 & Trial 3 \\
\hline \multicolumn{4}{|l|}{ Treatment factor and levels } \\
\hline \multirow[t]{2}{*}{ Sealing time } & Prompt $^{1}$ & Prompt & Prompt \\
\hline & Delay $^{2}$ & Delay & Delay \\
\hline \multirow[t]{2}{*}{ Storage temperature $\left({ }^{\circ} \mathrm{C}\right)$} & $20^{3}$ & & $20^{3}$ \\
\hline & & 35 & \\
\hline Aeration & & $\mathrm{AIN}^{5} 6$ times $^{3}$ & $\mathrm{NAI}^{4}$ \\
\hline \multirow[t]{3}{*}{ Silage additive } & $\mathrm{CON}^{6}$ & $\mathrm{CON}$ & CON \\
\hline & $\mathrm{SBSP}^{7}$ & SBSP & SBPS $^{8}$ \\
\hline & FAPA $^{9}$ & FAPA & $\mathrm{LAB}^{10}$ \\
\hline Storage time (d) & 101 & 141 & 90 \\
\hline Treatments (no.) & 6 & 12 & 12 \\
\hline Replicates (no.) & 3 & 3 & 3 \\
\hline \multicolumn{4}{|l|}{${ }^{1}$ Immediately ensiled. } \\
\hline \multirow{2}{*}{\multicolumn{4}{|c|}{$\begin{array}{l}{ }^{2} \text { Ensiled after being loosely piled at approximately } 16-18^{\circ} \mathrm{C} \text { for } 16 \mathrm{~h} \text { in trial } 1 \text { and } 2,24 \mathrm{~h} \text { in trial } 3 \text {. } \\
{ }^{3} \text { Constant experimental condition. }\end{array}$}} \\
\hline \multirow{2}{*}{\multicolumn{2}{|c|}{$\begin{array}{l}{ }^{2} \text { Constant experimental condition. } \\
{ }^{4} \mathrm{NAI}=\text { no air ingress. }\end{array}$}} & & \\
\hline \multirow{2}{*}{\multicolumn{4}{|c|}{$\begin{array}{l}{ }^{4} \mathrm{NAI}=\text { no air ingress. } \\
{ }^{5} \mathrm{AIN}=\text { air ingress for } 24 \mathrm{~h} \text { by remc }\end{array}$}} \\
\hline & & & \\
\hline \multicolumn{4}{|l|}{${ }^{6} \mathrm{CON}=$ no additive. } \\
\hline \multicolumn{4}{|c|}{$\begin{array}{l}{ }^{7} \text { SBSP }=\text { Maize Kofasil liquid (ADDCON GmbH, Bonn, Germany) containing sodium benzoate and sodium } \\
\text { propionate applied at } 4 \mathrm{~L} / \mathrm{t} \text {. }\end{array}$} \\
\hline \multicolumn{4}{|c|}{$\begin{array}{l}{ }^{8} \mathrm{SBPS}=\text { Kofasil stabil }(\mathrm{ADDCON} \mathrm{GmbH}) \text { containing sodium benzoate and potassium sorbate applied at } 2 \\
\mathrm{~L} / \mathrm{t} .\end{array}$} \\
\hline \multicolumn{4}{|c|}{$\begin{array}{l}{ }^{9} \mathrm{FAPA}=\text { GrasAAT Plus (ADDCON Nordic AS, Porsgrunn, Norway) representing a sodium buffered mixture } \\
\text { of formic, propionic acid and benzoic acids applied at } 4 \mathrm{~L} / \mathrm{t} \text {. }\end{array}$} \\
\hline \multicolumn{4}{|c|}{$\begin{array}{l}{ }^{10} \mathrm{LAB}=\text { Kofasil } \mathrm{LAC}(\mathrm{ADDCON} \mathrm{GmbH}) \text { homofermentative inoculant applied at } 2 \mathrm{~L} / \mathrm{t} \text {, giving an inoculation } \\
\text { rate of } 100,000 \mathrm{cfu} / \mathrm{g} .\end{array}$} \\
\hline
\end{tabular}

of approximately 16 to $18^{\circ} \mathrm{C}$ for 16 (trial 1 and 2 ) or $24 \mathrm{~h}$ (trial 3) before being filled in the silos (delay) and stored in a temperature-controlled room at $20^{\circ} \mathrm{C}$. Silages were packed in 1.5-L glass jar (Weck, Öfingen, Germany) without a gas-release valve, which were sealed with rubber O-rings and the lid fastened by metal clips. When repeated air ingress was allowed (experiments 2 and 3), the same glass jars were used but these had one hole of $6 \mathrm{~mm}$ diameter each in the lid and in the body of the jar (about $5 \mathrm{~cm}$ above the bottom), which were closed by rubber stoppers. All treatments were ensiled in triplicate.

In experiment 1, corn (unknown variety, $31 \% \mathrm{DM}$ ) was harvested at dough stage maturity by a chopper (Haldrup, Løgstør, Denmark) on October 1, 2007, on a dairy farm near Oldenburg, Lower-Saxony, Germany. The forage was treated with no additive $(\mathbf{C O N})$ or with $4 \mathrm{~L} / \mathrm{t}$ of Maize Kofasil liquid (SBSP; ADDCON GmbH, Bonn, Germany; containing 259 g/L of sodium benzoate and $94 \mathrm{~g} / \mathrm{L}$ of sodium propionate) or $4 \mathrm{~L} / \mathrm{t}$ of GrasAAT Plus (FAPA; ADDCON Nordic AS, Porsgrunn, Norway; containing $350 \mathrm{~g} / \mathrm{L}$ of formic, $120 \mathrm{~g} / \mathrm{L}$ of propionic, and $18 \mathrm{~g} / \mathrm{L}$ of benzoic acids buffered with sodium). In total, 18 silages were stored for $101 \mathrm{~d}$ (9 for prompt and 9 for delay silos).

In experiment 2, the same crop, harvesting method, and silage additive treatments were used as in experi- ment 1 . However, the material of the 3 additive treatments with prompt and delay sealing were transferred into silos equipped with holes closed by rubber stoppers. On d 28, 42, 52, 73, 105, and 129 of fermentation, the rubber stoppers were removed from each jar for 24 $\mathrm{h}$ to allow air ingress. Half of the jars were stored at $20^{\circ} \mathrm{C}$ (cool) and half at $35^{\circ} \mathrm{C}($ hot $)$. All silos $(\mathrm{n}=36)$ were opened after $141 \mathrm{~d}$ of storage.

In experiment 3, corn (var. Fernandez) was chopped at dough stage $(34.9 \% \mathrm{DM})$ by commercial harvesting equipment on September 22, 2009, on a dairy farm near Oldenburg, Lower-Saxony, Germany. The forage was either left untreated $(\mathrm{CON})$ or received $2 \mathrm{~L} / \mathrm{t}$ of Kofasil Stabil (SBPS; ADDCON GmbH; containing $250 \mathrm{~g} / \mathrm{L}$ of sodium benzoate and $150 \mathrm{~g} / \mathrm{L}$ of potassium sorbate) or $2 \mathrm{~L} / \mathrm{t}$ of an aqueous suspension of Kofasil LAC (LAB; ADDCON GmbH; composed of lyophilized Lactobacillus plantarum DSM 3676, 50\% and Lactobacillus plantarum DSM 3677, 50\%, achieving a total inoculation rate of $100,000 \mathrm{cfu} / \mathrm{g}$ of fresh forage), respectively. Prompt and delay silages were divided into 2 treatments of air ingress during fermentation, which were no air ingress (NAI) or air ingress (AIN). The material for NAI treatment was ensiled in glass jars without holes, whereas AIN forage was packed in those with a hole in the jar body and the lid to enable air ingress for $24 \mathrm{~h}$ by removing the rubber stoppers on 
d 28, 42, and 83 of fermentation. All jars $(\mathrm{n}=36)$ were opened after $90 \mathrm{~d}$ of storage.

Analytical Procedures. Silage samples were thoroughly mixed after withdrawal from farm and laboratory silos, and frozen at $-20^{\circ} \mathrm{C}$ until chemical analysis. Silage extracts were prepared by blending $50 \mathrm{~g}$ of silage with $200 \mathrm{~mL}$ of distilled water. After addition of $1 \mathrm{~mL}$ of toluene and storage at $4^{\circ} \mathrm{C}$ in the refrigerator overnight, the extracts were subsequently filtered through a folded paper filter and thereafter through a microfilter $(0.45 \mu \mathrm{m})$. Lactic acid was determined by HPLC and refraction index detection (Weiss and Kaiser, 1995), whereas acetic acid, ethanol, 1,2-propanediol, and npropanol were detected by GC using a free fatty acid phase (Macherey-Nagel, Düren, Germany) column and flame ionization detector (FID; Weiss, 2001). The limit of detection for each parameter was $0.01 \%$ of fresh matter. In experiments 1 and 2, ethyl esters of lactate and acetate were analyzed according to Adam et al. (1995). After water steam distillation of the samples, individual components were measured by GC and the FID detector coupled with a capillary and packed glass column. The limit of detection was $0.3 \mathrm{mg} / \mathrm{L}$ for ethyl acetate and $0.2 \mathrm{mg} / \mathrm{L}$ for ethyl lactate. Ethyl esters of lactic and acetic acids were determined by GC with FID using an Optima Wax column (Macherey-Nagel) in experiment 3. Extracts were supplemented with the internal standard 2-methyl pentanol. The detailed description of the method including its precision parameters was published by Weiss and Sommer (2012). The detection limit of esters was determined to be 3 $\mathrm{mg} / \mathrm{L}$ or $0.001 \%$ of fresh matter. Aerobic stability of the silages was measured over 7 or $10 \mathrm{~d}$ by using the temperature method according to Honig (1990). Silage was placed in an insulated box with data loggers inserted into the geometric center and stored at $20^{\circ} \mathrm{C}$. Silages were considered aerobically unstable once the silage temperature had reached $3^{\circ} \mathrm{C}$ above ambient. The count of lactate-assimilating yeasts was determined by spread-plating serial dilutions of silage extracts on yeasts-nitrogen-base agar with lactate as the sole carbon source and aerobic incubation at $25^{\circ} \mathrm{C}$ for $3 \mathrm{~d}$ (Jonsson and Pahlow, 1984). The limit of detection of this method was $10^{2} \mathrm{cfu} / \mathrm{g}$ of fresh matter. Silage DM was corrected for the loss of volatiles during drying as described by Weissbach and Strubelt (2008). All values are given on a DM basis are expressed as grams per kilogram of corrected DM.

\section{Statistical Analyses}

The counts of lactate-assimilating yeasts values were log-transformed before analysis and presented as log values. Yeast numbers below the limit of detection of $10^{2} \mathrm{cfu} / \mathrm{g}$ of fresh matter were set at the detection limit of $\log 2.0$. Statistical analyses were performed with SAS Version 9.3 (SAS Institute Inc., Cary, NC). For treatment comparisons, the ANOVA was used assuming a fixed effect model (Littell et al., 2006) for a completely randomized design. Initially, residuals were tested for normal distribution by Shapiro-Wilk-Test (Proc UNIVARIATE). Data on the count of lactate-assimilating yeasts and aerobic stability data, for which normal distribution could not be assumed, was transformed into ranks and analyzed with an ANOVA-type statistical model for the global $F$ test and pairwise comparisons among the rank means (Proc MIXED). For all other variables and for log-transformed n-propanol values normal distribution could be assumed. For consideration of possible variance heterogeneity, different approaches were evaluated. Approach I assumed variance homogeneity (using one residual variance), whereas approach II assumed variance heterogeneity (using separate residual variances per level of only one factor or per factor level combination of 2 or 3 factors). The model fit of the different approaches was evaluated by the Akaike information criterion and the likelihood ratio test, respectively. The ANOVA was performed by Proc MIXED using the restricted maximum-likelihood algorithm (Schabenberger and Pierce, 2002). When significant treatment effects were detected by the global $F$ test, pairwise comparisons were performed by Tukey's test taking into account the interactions between the treatment factors. In all trials, the cell means (LSMEANS of all factor level combinations) were compared and marginal means only in case of no corresponding interaction. For trial 3, marginal means were not compared due to factor interactions in almost all situations. In addition, the $t$-test was used for a special contrast between additive treatments in experiment 3 . The procedures CORR and REG were employed to evaluate the relationships between individual silage fermentation characteristics by simple, multiple and partial coefficient of determination using multiple regression analysis.

\section{RESULTS}

\section{Farm Survey}

The fermentation characteristics of the farm silages are summarized in Table 2. Regardless of additive use and additive type, lactic acid was detected at typical levels for corn silage. Acetic acid content was lowest in one silage inoculated with homofermentative LAB, and the only sample that had been treated with heterofer- 
Table 2. Concentrations of organic acids, alcohols, and ethyl esters in farm corn silages from the State of Brandenburg in 2009 (g/kg of DM unless stated otherwise)

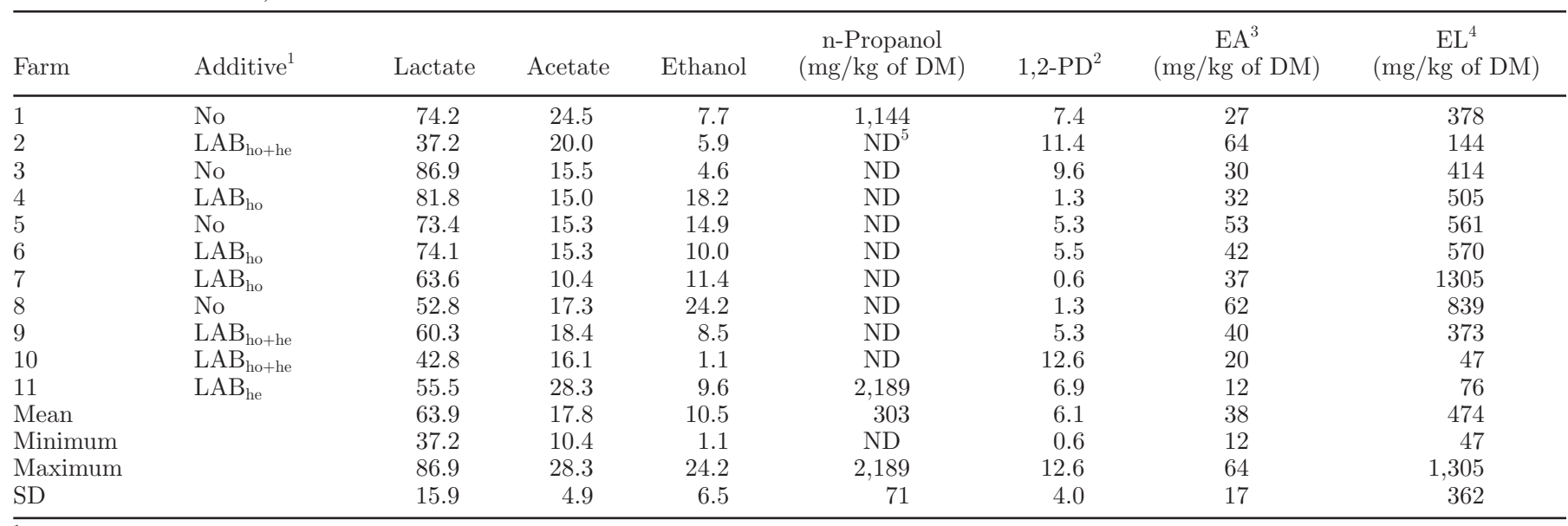

${ }^{1} \mathrm{LAB}_{\mathrm{ho}}=$ homofermentative lactic acid bacteria; $\mathrm{LAB}_{\mathrm{ho}+\mathrm{he}}=$ mixture of homo- and heterofermentative lactic acid bacteria; $\mathrm{LAB}_{\mathrm{he}}=$ heterofermentative lactic acid bacteria.

${ }^{2} 1,2$-Propanediol.

${ }^{3}$ Ethyl acetate.

${ }^{4}$ Ethyl lactate.

${ }^{5} \mathrm{ND}=$ below detection limit of $0.01 \%$ of fresh matter.

mentative LAB contained the highest amount. Whereas ethanol was found in all samples at concentrations of up to $24.2 \mathrm{~g} / \mathrm{kg}$ of DM, n-propanol was rarely detected and only at much lower contents. All corn silages contained 1,2-propanediol at largely varying contents of up to $12.6 \mathrm{~g} / \mathrm{kg}$ of DM. Ethyl esters of lactic and acetic acids were detected in all samples, but the mean ethyl lactate level was higher than that of ethyl acetate (474 vs. $38 \mathrm{mg} / \mathrm{kg}$ of DM). Untreated silages and those that received only homofermentative $\mathrm{LAB}$ had the highest ethyl lactate concentrations ranging from 378 to 1,305 $\mathrm{mg} / \mathrm{kg}$ of DM.

\section{Experiment 1}

Silage $\mathrm{pH}$ ranged between 3.67 and 3.80 at typical levels for corn silages (data not presented). Lactic acid concentration of untreated prompt silages was greater than in untreated delay silages (Table 3). This difference was less pronounced when silages were treated with the additive SBSP. On the contrary, the additive FAPA increased lactic acid content in delay silages compared with prompt silages. Delayed sealing tended to increase acetate concentrations $(P=0.074)$. Untreated silages contained the highest concentrations of acetic acid, followed by the SBSP and FAPA treatments $(P<0.001)$. We noted a trend toward lower ethanol formation by delayed sealing $(P=0.081)$. The addition of FAPA resulted in the highest concentration of ethanol regardless of sealing time. Untreated prompt silages contained more n-propanol than was detected in untreated delay silages. The use of all additives led to lower n-propanol formation in prompt silages. In delay silages this effect was only noticed for additive FAPA. Prompt and delay silages treated with FAPA had greater concentrations of ethyl acetate and ethyl lactate when compared with untreated or SBSP treated silages. The use of additive SBSP stimulated ester formation in delay silages when compared with untreated silage. Regardless of treatment, the yeast count after $101 \mathrm{~d}$ of fermentation was below the detection limit of $10^{2} \mathrm{cfu} / \mathrm{g}$, and all silages were stable over the entire period of $7 \mathrm{~d}$ of exposure to air (data not shown).

\section{Experiment 2}

The $\mathrm{pH}$ of the silages varied within the normal range for corn silage between 3.81 and 4.07 (data not shown). The trial conditions affected the contents of lactic and acetic acids strongly, and interactions between temperature, additive, and sealing time existed. As shown in Table 4, lactate concentrations were lower in untreated delay silages than in untreated prompt silages, and lower in untreated hot than in untreated cool silages. The effect of additives regarding higher contents of lactic acid was only observed in hot silages. Delay, hot CON silages contained the lowest lactate concentration. Prompt, hot FAPA silages showed a content of lactic acid similar to that of prompt, cool CON, but also the lowest content of acetic acid. Only in prompt 
Table 3. Effects of sealing time (S; 0 h, prompt vs. 16-h delay) and additive (A) use on fermentation characteristics and volatile organic compounds of corn silage $(\mathrm{n}=3)$ after $101 \mathrm{~d}$ of fermentation $(\mathrm{g} / \mathrm{kg}$ of $\mathrm{DM}$ unless stated otherwise)

\begin{tabular}{|c|c|c|c|c|c|c|c|}
\hline Sealing time & Additive $^{1}$ & Lactate & Acetate & Ethanol & $\begin{array}{c}\text { n-Propanol }{ }^{2} \\
(\mathrm{mg} / \mathrm{kg} \text { of } \mathrm{DM})\end{array}$ & $\begin{array}{c}\mathrm{EA}^{3} \\
(\mathrm{mg} / \mathrm{kg} \text { of } \mathrm{DM})\end{array}$ & $\begin{array}{c}\mathrm{EL}^{4} \\
(\mathrm{mg} / \mathrm{kg} \text { of } \mathrm{DM})\end{array}$ \\
\hline $\begin{array}{l}\text { Prompt } \\
\text { Delay }\end{array}$ & $\begin{array}{l}\text { CON } \\
\text { SBSP } \\
\text { FAPA }\end{array}$ & & $\begin{array}{c}13.1^{\mathrm{A}} \\
16.6^{\mathrm{A}} \\
19.9^{\mathrm{B}} \\
16.0^{\mathrm{AB}} \\
8.7^{\mathrm{A}}\end{array}$ & $\begin{array}{r}15.5^{\mathrm{A}} \\
13.0^{\mathrm{A}} \\
6.1^{\mathrm{A}} \\
6.7^{\mathrm{A}} \\
30.0^{\mathrm{B}}\end{array}$ & & & \\
\hline Prompt & $\begin{array}{l}\text { CON } \\
\text { SBSP } \\
\text { FAPA }\end{array}$ & $\begin{array}{l}55.2^{\mathrm{b}} \\
65.2^{\mathrm{bc}} \\
56.7^{\mathrm{b}}\end{array}$ & $\begin{array}{l}17.4^{\mathrm{b}} \\
13.6^{\mathrm{ab}} \\
8.3^{\mathrm{a}}\end{array}$ & $\begin{array}{r}6.8^{\mathrm{a}} \\
6.2^{\mathrm{a}} \\
33.6^{\mathrm{b}}\end{array}$ & $\begin{array}{r}2,434^{\mathrm{d}} \\
625^{\mathrm{b}} \\
27^{\mathrm{a}}\end{array}$ & $\begin{array}{r}66^{\mathrm{a}} \\
48^{\mathrm{a}} \\
137^{\mathrm{b}}\end{array}$ & $\begin{array}{l}181^{\mathrm{bc}} \\
163^{\mathrm{b}} \\
349^{\mathrm{d}}\end{array}$ \\
\hline Delay & $\begin{array}{l}\text { CON } \\
\text { SBSP } \\
\text { FAPA }\end{array}$ & $\begin{array}{l}36.5^{\mathrm{a}} \\
47.0^{\mathrm{ab}} \\
67.1^{\mathrm{c}}\end{array}$ & $\begin{array}{c}22.4^{\mathrm{b}} \\
18.3^{\mathrm{ab}} \\
9.1^{\mathrm{a}}\end{array}$ & $\begin{array}{r}5.3^{\mathrm{a}} \\
7.2^{\mathrm{a}} \\
26.4^{\mathrm{b}}\end{array}$ & $\begin{array}{r}892^{\mathrm{bc}} \\
1,067^{\mathrm{c}} \\
33^{\mathrm{a}}\end{array}$ & $\begin{array}{r}72^{\mathrm{a}} \\
113^{\mathrm{b}} \\
176^{\mathrm{c}}\end{array}$ & $\begin{array}{l}105^{\mathrm{a}} \\
212^{\mathrm{c}} \\
373^{\mathrm{d}}\end{array}$ \\
\hline $\begin{array}{l}\text { SEM } \\
\text { Effects }^{5}\end{array}$ & $\begin{array}{l}\mathrm{S} \\
\mathrm{A} \\
\mathrm{S} \times \mathrm{A}\end{array}$ & $\begin{aligned} & 1.2-3.7 \\
& 0.004 \\
< & 0.001 \\
< & 0.001\end{aligned}$ & $\begin{aligned} & 0.7-3.1 \\
& 0.074 \\
&< 0.001 \\
& 0.194\end{aligned}$ & $\begin{array}{c}0.6-2.2 \\
0.081 \\
<0.001 \\
0.197\end{array}$ & $\begin{aligned} & 1-110 \\
& 0.202 \\
< & 0.001 \\
< & 0.001\end{aligned}$ & $\begin{aligned} & 7 \\
< & 0.001 \\
< & 0.001 \\
& 0.003\end{aligned}$ & $\begin{array}{r}5-12 \\
0.935 \\
<0.001 \\
<0.001\end{array}$ \\
\hline
\end{tabular}

\footnotetext{
${ }^{\mathrm{A}, \mathrm{B}}$ Marginal means for each factor within columns are significantly different if they have no letters in common $(P<0.05$; Tukey's test).

${ }^{\mathrm{a}-\mathrm{d}}$ Cell means within columns are significantly different if they have no letters in common $(P<0.05$; Tukey's test).

${ }^{1} \mathrm{CON}=$ untreated; SBSP = Maize Kofasil liquid (ADDCON GmbH, Bonn, Germany) containing sodium benzoate and sodium propionate applied at $4 \mathrm{~L} / \mathrm{t}$; FAPA = GrasAAT (ADDCON Nordic AS, Porsgrunn, Norway) containing formic, propionic acid and benzoic acids buffered with sodium and applied at $4 \mathrm{~L} / \mathrm{t}$.

${ }^{2}$ Analysis based on log-transformed data.

${ }^{3}$ Ethyl acetate.

${ }^{4}$ Ethyl lactate.

${ }^{5} P$-values of global F-test.
}

untreated silages did the higher storage temperature lead to increased acetate levels. No other treatments had an effect on this variable. Despite weak interactions between sealing time, temperature, and silage additives $(P=0.029)$, FAPA-treated silages had greater amounts of ethanol than any other treated silage (14.0 vs. 4.5 in CON vs. $3.0 \mathrm{~g} / \mathrm{kg}$ of DM in SBSP; $P<0.001)$. The concentration of n-propanol in untreated silages was higher in prompt than in delay silages (1,914 vs. 1,094 $\mathrm{mg} / \mathrm{kg}$ of $\mathrm{DM} ; P=0.009$ ) and consistently lower in cool than in hot silages $(130$ vs. $243 \mathrm{mg} / \mathrm{kg}$ of DM; $P=$ 0.001 ). Both additives reduced n-propanol, but the effect was more pronounced with FAPA. Delayed sealing stimulated ethyl acetate formation ( 52 vs. $81 \mathrm{mg} / \mathrm{kg}$ of DM; $P=0.025$ ) but decreased ethyl lactate content (119 vs. $90 \mathrm{mg} / \mathrm{kg}$ of DM; $P=0.005$ ) compared with prompt silages. Storage at low temperature always resulted in higher ethyl lactate formation, whereas ethyl acetate was only increased when the additive FAPA had been used (temperature $\times$ treatment interaction; $P=0.004)$. The highest levels of both ethyl esters were associated with FAPA application in cool silages. As shown in Table 5 , storage at the lower temperature resulted in higher numbers of yeasts $(P=0.008)$ in prompt silages but additive had an influence on this variable. Hot silages were more stable upon exposure to air than cool silages (6.3-7.0 vs. $2.0-6.7 \mathrm{~d} ; P<0.001)$.

\section{Experiment 3}

The $\mathrm{pH}$ ranged between 3.82 and 4.00 (data not shown), and n-propanol was not detected in any of the silages. Delayed sealing reduced lactate content compared with prompt sealing for all aeration $\times$ additive combinations to varying extents, as did the use of the additive SBPS in prompt sealed silages when compared with CON and LAB silages (Table 6). Acetate contents determined in CON and LAB silages were significantly higher compared with silages treated with the additive SBPS when silages were sealed with delay (16.1 vs. $11.0 \mathrm{~g} / \mathrm{kg}$ of DM; $P<0.05)$. This effect was stronger when silages were also aerated (23.8 vs. $12.9 \mathrm{~g} / \mathrm{kg}$ of $\mathrm{DM} ; P<0.05)$. For prompt silages, the acetate content varied between 8.5 and $12.7 \mathrm{~g} / \mathrm{kg}$ of DM and only small differences were detected between treatments. Interactions existed between all examined factors. Regardless of sealing time and air ingress, the contents of ethanol were comparable between $\mathrm{CON}$ and $\mathrm{LAB}$ with the exception of prompt, CON, AIN silages, which had the highest content of all treatments. The difference between SBPS and the other additive treatments was affected by other factors (sealing time $\times$ additive interaction, $P=0.003$; aeration $\times$ additive interaction, $P<$ $0.001)$. In prompt and delay silages without air ingress, treatment with SBPS resulted in the lowest ethanol 


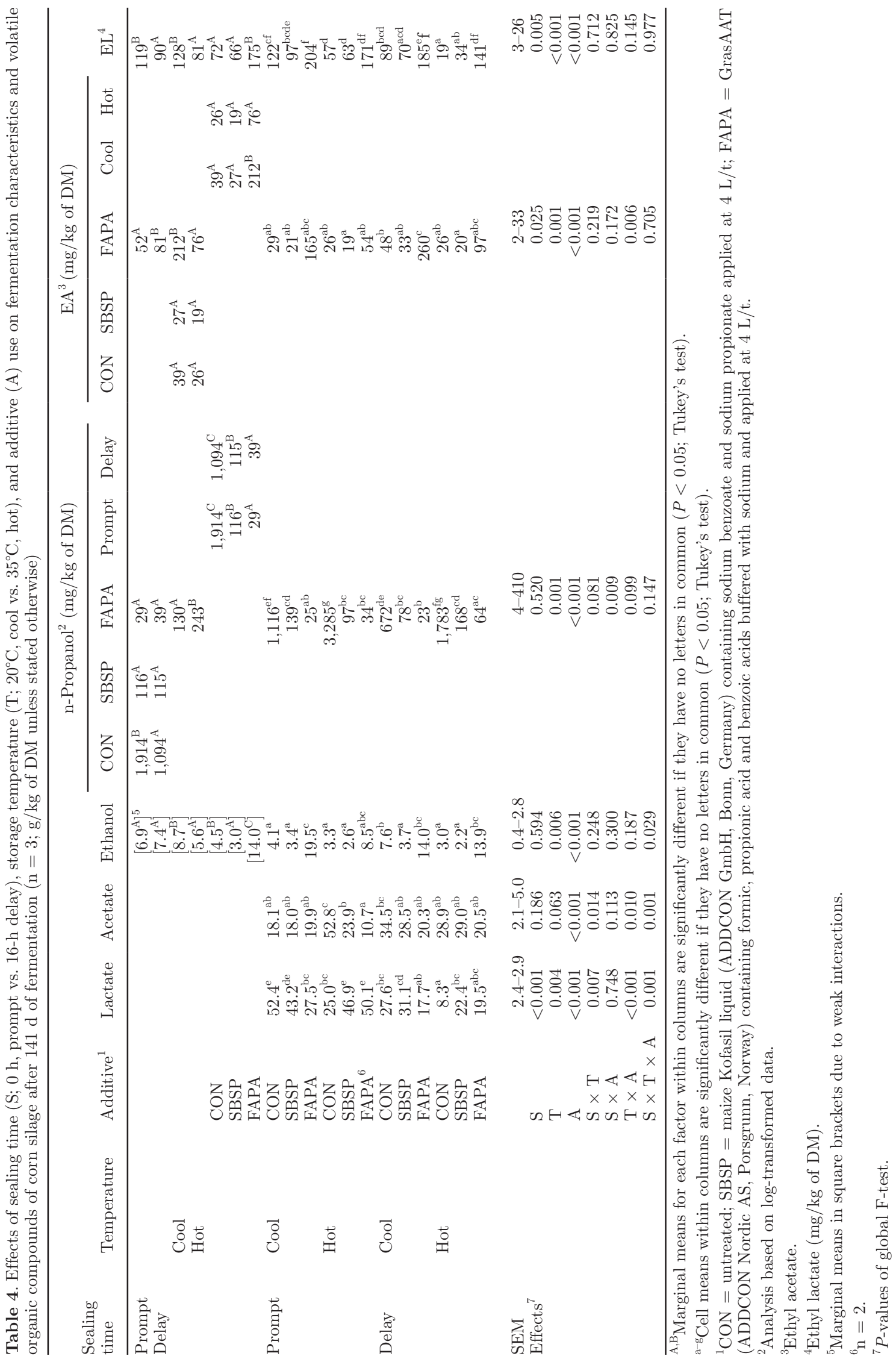


concentrations (5.7-7.9 vs. $11.8-13.6 \mathrm{~g} / \mathrm{kg}$ of DM) compared with any other additive treatment. In the AIN silages, the effect of this additive was less pronounced. However, SBPS consistently reduced ethanol production when compared with CON and LAB. Larger ethyl acetate concentrations were found in $\mathrm{CON}$ and $\mathrm{LAB}$ silages compared with SBPS silages with the difference being more pronounced in delay (NAI: 286 vs. 60, AIN: 301 vs. $96 \mathrm{mg} / \mathrm{kg}$ of DM) than in prompt silages (NAI: 157 vs. 26 , AIN: 131 vs. $68 \mathrm{mg} / \mathrm{kg}$ of DM). The level of ethyl lactate was reduced by the additive SBPS but the magnitude of the effect depended on other factor levels. The strongest effects of SBPS were found in prompt silages (NAI: 191 vs. 37, AIN: 157 vs. $97 \mathrm{mg} /$ $\mathrm{kg}$ of DM) compared with delay silages (NAI: 146 vs. 70, AIN: 115 vs. $62 \mathrm{mg} / \mathrm{kg}$ of DM). The SBPS consistently reduced the concentrations of both ethyl esters. Lower yeast numbers were detected (Table 7 ) in delay than in prompt silages $(P=0.002)$. Air ingress during fermentation in prompt silages resulted in increased yeast counts; additive use had no effect on yeast count. We found no influence of aeration on aerobic stability. The additive SBPS enhanced aerobic stability (10 d) in prompt silages in comparison to $\mathrm{CON}(2.3-4.7 \mathrm{~d})$ and LAB (1.8-5.5 d) treatments. Both CON and LAB silages ensiled with delay showed the same high aerobic stability as those treated with SBPS.

\section{Relationships Between Fermentation Characteristics and VOC}

The variation in the concentrations of measured ethyl esters can be largely attributed to the content of the reaction partners, ethanol and lactic or acetic acids (Table 8). Multiple coefficients of determination ranged from 0.515 to 0.841 (for all models and trials $P<0.001$ for overall $F$-tests) depending on the experiment. In experiments 1 and 2, only ethanol was correlated with ethyl acetate formation (regression coefficients are 2.82 and $9.34 \mathrm{mg}$ of ethyl acetate per $1 \mathrm{~g}$ of ethanol when acetic acid values are constant; $P<0.01$ and $P$ $<0.001)$. On the contrary, in experiment 3 acetic acid had a larger apparent effect (14.4 mg of ethyl acetate per $1 \mathrm{~g}$ of acetic acid when ethanol values are constant; $P<0.001)$ than was observed for ethanol $(11.3 \mathrm{mg}$ of ethyl acetate per $1 \mathrm{~g}$ of ethanol when acetic acid values are constant; $P<0.01)$. The apparent effect of ethanol on ethyl lactate was always larger (6.84 to $10.1 \mathrm{mg}$ of ethyl lactate per $1 \mathrm{~g}$ of ethanol when lactic acid values are constant; $P<0.001)$ than that of lactic acid (1.71 to $2.70 \mathrm{mg}$ of ethyl lactate per $1 \mathrm{~g}$ of lactic acid when ethanol values are constant). With regard to total ethyl ester levels, it can be stated that only ethanol was important in experiments 1 and 2 whereas in experiment 3 the model was improved by including acetic acid.

Table 5. Effects of sealing time ( $\mathrm{S} ; 0$ h, prompt vs. 16 -h delay), storage temperature $\left(\mathrm{T} ; 20^{\circ} \mathrm{C}\right.$, cool vs. $35^{\circ} \mathrm{C}$, hot), and additive (A) use on the count of lactate-assimilating yeasts and aerobic stability of corn silage after $141 \mathrm{~d}$ of fermentation $(\mathrm{n}=3)$

\begin{tabular}{|c|c|c|c|c|}
\hline $\begin{array}{l}\text { Sealing } \\
\text { time }\end{array}$ & Temperature & Additive $^{1}$ & $\begin{array}{l}\text { Yeast count } \\
(\log \mathrm{cfu} / \mathrm{g})\end{array}$ & $\begin{array}{c}\text { Aerobic } \\
\text { stability (d) }\end{array}$ \\
\hline \multirow[t]{6}{*}{ Prompt } & \multirow[t]{3}{*}{ Cool } & $\mathrm{CON}$ & $5.8^{\mathrm{b}}$ & $3.8^{\mathrm{ab}}$ \\
\hline & & SBSP & $3.6^{\mathrm{ab}}$ & $\begin{array}{l}5.0 \\
6.7^{\mathrm{bc}}\end{array}$ \\
\hline & & FAPA & $3.8^{\mathrm{ab}}$ & $5.5^{\mathrm{abc}}$ \\
\hline & \multirow[t]{3}{*}{ Hot } & $\mathrm{CON}$ & $<2.0^{\mathrm{a}}$ & $7.0^{\mathrm{c}}$ \\
\hline & & SBSP & $<2.0^{\mathrm{a}}$ & $7.0^{\mathrm{c}}$ \\
\hline & & FAPA & $2.2^{\mathrm{ab}}$ & $7.0^{\mathrm{c}}$ \\
\hline \multirow[t]{6}{*}{ Delay } & \multirow[t]{3}{*}{ Cool } & $\mathrm{CON}$ & $<2.0^{\mathrm{a}}$ & $6.1^{\mathrm{abc}}$ \\
\hline & & SBSP & $<2.0^{\mathrm{a}}$ & $2.0^{\mathrm{a}}$ \\
\hline & & FAPA & $<2.0^{\mathrm{a}}$ & $3.4^{\mathrm{b}}$ \\
\hline & \multirow[t]{3}{*}{ Hot } & $\mathrm{CON}$ & $<2.0^{\mathrm{a}}$ & $7.0^{\mathrm{c}}$ \\
\hline & & SBSP & $<2.0^{\mathrm{a}}$ & $6.3^{\mathrm{abc}}$ \\
\hline & & FAPA & $<2.0^{\mathrm{a}}$ & $6.8^{\mathrm{bc}}$ \\
\hline \multirow[t]{7}{*}{ Effects $^{2}$} & & S & 0.066 & 0.060 \\
\hline & & $\mathrm{T}$ & 0.008 & $<0.001$ \\
\hline & & A & 0.573 & 0.540 \\
\hline & & $\mathrm{S} \times \mathrm{T}$ & 0.008 & 0.659 \\
\hline & & $\mathrm{S} \times \mathrm{A}$ & 0.573 & 0.007 \\
\hline & & $\mathrm{T} \times \mathrm{A}$ & 0.312 & 0.935 \\
\hline & & $\mathrm{S} \times \mathrm{T} \times \mathrm{A}$ & 0.312 & 0.046 \\
\hline
\end{tabular}

${ }^{\mathrm{a}-\mathrm{c}}$ Means within a column are significantly different if they have no letters in common $(P<0.05$, non-parametric rank test).

${ }^{1} \mathrm{CON}=$ untreated; SBSP = Maize Kofasil liquid (ADDCON GmbH, Bonn, Germany) containing sodium benzoate and sodium propionate applied at $4 \mathrm{~L} / \mathrm{t} ;$ FAPA = GrasAAT (ADDCON Nordic AS, Porsgrunn, Norway) containing formic, propionic acid and benzoic acids buffered with sodium and applied at $4 \mathrm{~L} / \mathrm{t}$.

${ }^{2} P$-values of global rank test (ANOVA type statistics). 
Table 6. Effects of sealing time (S; 0 h, prompt vs. 24-h delay), aeration [AE; no air ingress (NAI) vs. air ingress (AIN)] and additive (A) use on fermentation characteristics and volatile organic compounds of corn silage after $90 \mathrm{~d}$ of fermentation $(\mathrm{n}=3 ; \mathrm{g} / \mathrm{kg}$ of DM unless stated otherwise)

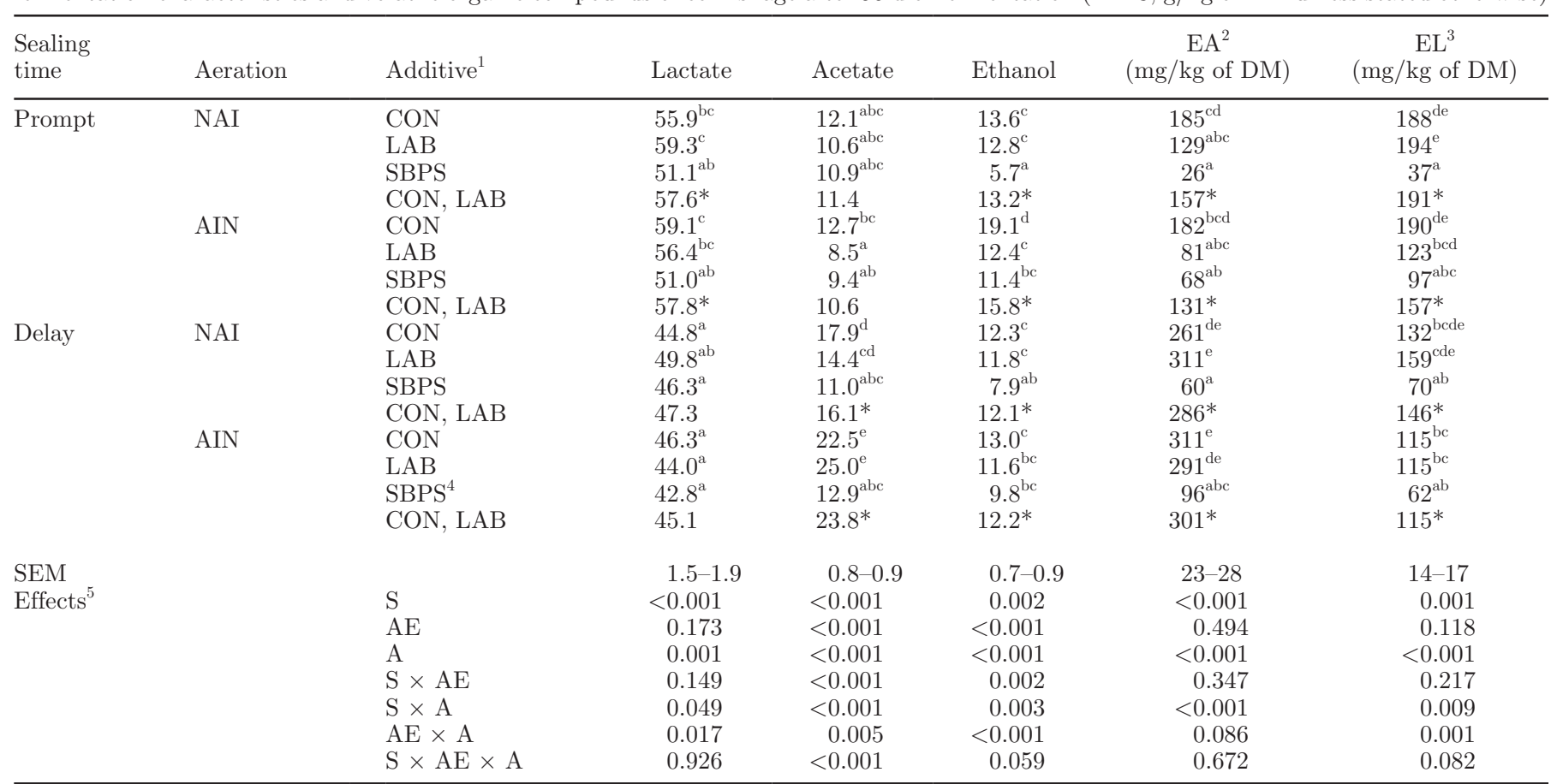

\footnotetext{
${ }^{2}$ Ethyl acetate.

${ }^{3}$ Ethyl lactate.

${ }^{4} \mathrm{n}=2$.

${ }^{5} P$-values of global F-test.

*Significant contrast for $(\mathrm{CON}+\mathrm{LAB}) / 2$ vs. SBPS $(P<0.05, t$-test $)$.
}

${ }^{\mathrm{a} e}$ Means within a column are significantly different if they have no letters in common $(P<0.05$; Tukey's test);

${ }^{1} \mathrm{CON}=$ untreated; LAB = Kofasil LAC (ADDCON GmbH, Bonn, Germany) homofermentative inoculant applied at an inoculation rate of $100,000 \mathrm{cfu} / \mathrm{g} ;$ SBPS $=$ Kofasil Stabil $($ ADDCON GmbH) containing sodium benzoate and potassium sorbate applied at $2 \mathrm{~L} / \mathrm{t}$.

\section{DISCUSSION}

\section{Farm Survey}

According to Kung and Shaver (2001), the fermentation pattern of the farm silages was within the typical range for lactate, acetate, and ethanol despite the fact that they were characterized by atypical smell and were believed to have contributed to feed intake depression. The variables 1,2-propanediol, n-propanol, and especially ethyl esters are yet not used in silage evaluation. The sole use homofermentative inoculants in corn silage under farm and experimental conditions (experiment 3) appears not to increase lactic acid production due to the typically high numbers of epiphytic LAB $\left(>10^{6}\right.$ $\mathrm{cfu} / \mathrm{g}$ ) on the crop at ensiling (Schmidt and Kung, 2010), which makes it very difficult for the added LAB to dominate the fermentation process. The large variation in lactate, acetate, and ethanol concentrations of the corn silages observed in our study supported previous findings from a large number of farms in the United States, Denmark, and Italy (Mari et al., 2009; Borreani and Tabacco, 2010; Kristensen et al., 2010; Tabacco et al., 2011). This may be associated with differences in the epiphytic populations of the crops at ensiling, climatic and silage management factors, and storage temperature. For example, the effect of air by delayed sealing and air infiltration during the fermentation process showed, although not consistently, an influence on the fermentation pattern of corn silage. Also, the use of different inoculant types may partially explain alterations in fermentation patterns. In our farm survey, corn silage solely treated with heterofermentative LAB containing Lactobacillus buchneri had the highest acetic acid concentration, but this inoculant type was not tested in our ensiling experiments. Our observation that all farm silages contained 1,2-propanediol, which was not measured in the ensiling experiments, is likely attributable to the presence of epiphytic Lactobacillus buchneri on the crop at harvest and its activity during the fermentation process. This species, whose presence varies with location (Schmidt and Kung, 2010), is the only known 1,2-propanediol producer in silage converting lactate into acetate and this compound (Oude- 
Table 7. Effects of sealing time (S; 0 h, prompt vs. 24-h delay), aeration [AE; no air ingress (NAI) vs. air ingress (AIN)] and additive (A) use count of lactate-assimilating yeasts and aerobic stability of corn silage after $90 \mathrm{~d}$ of fermentation $(\mathrm{n}=3)$

\begin{tabular}{|c|c|c|c|c|}
\hline $\begin{array}{l}\text { Sealing } \\
\text { time }\end{array}$ & Aeration & Additive $^{1}$ & $\begin{array}{l}\text { Yeast count } \\
(\log \mathrm{cfu} / \mathrm{g})\end{array}$ & $\begin{array}{l}\text { Aerobic stability } \\
\text { (d) }\end{array}$ \\
\hline Prompt & $\begin{array}{l}\text { NAI } \\
\text { AIN }\end{array}$ & $\begin{array}{l}\text { CON } \\
\text { LAB } \\
\text { SBPS } \\
\text { CON } \\
\text { LAB } \\
\text { SBPS }\end{array}$ & $\begin{array}{c}3.4^{\mathrm{b}} \\
2.9^{\mathrm{abc}} \\
<2.0^{\mathrm{a}} \\
5.9^{\mathrm{cd}} \\
6.5^{\mathrm{c}} \\
4.3^{\mathrm{bd}}\end{array}$ & $\begin{array}{c}4.7^{\mathrm{bc}} \\
5.5^{\mathrm{c}} \\
10.0^{\mathrm{d}} \\
2.3^{\mathrm{ab}} \\
1.8^{\mathrm{a}} \\
10.0^{\mathrm{d}}\end{array}$ \\
\hline Delay & $\begin{array}{l}\text { NAI } \\
\text { AIN }\end{array}$ & $\begin{array}{l}\text { CON } \\
\text { LAB } \\
\text { SBPS } \\
\text { CON } \\
\text { LAB } \\
\text { SBPS }\end{array}$ & $\begin{aligned} &<2.0^{\mathrm{a}}<2.0^{\mathrm{a}} \\
&<2.0^{\mathrm{a}} \\
&<2.0^{\mathrm{a}} \\
& 3.5^{\mathrm{abc}} \\
&<2.0^{\mathrm{a}}\end{aligned}$ & $\begin{array}{c}10.0^{\mathrm{d}} \\
10.0^{\mathrm{d}} \\
7.8^{\mathrm{bcd}} \\
10.0^{\mathrm{d}} \\
10.0^{\mathrm{d}} \\
10.0^{\mathrm{d}}\end{array}$ \\
\hline Effects $^{2}$ & & $\begin{array}{l}\mathrm{S} \\
\mathrm{AE} \\
\mathrm{A} \\
\mathrm{S} \times \mathrm{AE} \\
\mathrm{S} \times \mathrm{A} \\
\mathrm{AE} \times \mathrm{A} \\
\mathrm{S} \times \mathrm{AE} \times \mathrm{A}\end{array}$ & $\begin{array}{l}0.002 \\
0.005 \\
0.147 \\
0.012 \\
0.133 \\
0.150 \\
0.493\end{array}$ & $\begin{array}{l}0.005 \\
0.294 \\
0.028 \\
0.065 \\
0.013 \\
0.144 \\
0.684\end{array}$ \\
\hline
\end{tabular}

${ }^{\mathrm{a}-\mathrm{d}}$ Means within a column are significantly different if they have no letters in common $(P<0.05$; nonparametric rank test).

${ }^{1} \mathrm{CON}=$ untreated; LAB = Kofasil LAC (ADDCON GmbH, Bonn, Germany) homofermentative inoculant applied at an inoculation rate of 100,000 $\mathrm{cfu} / \mathrm{g}$; SBPS = Kofasil Stabil (ADDCON GmbH) containing sodium benzoate and potassium sorbate applied at $2 \mathrm{~L} / \mathrm{t}$.

${ }^{2} P$-values of global rank test (ANOVA type statistics).

Elferink et al., 2001). In our study, n-propanol was detected less frequently and at lower concentrations compared with previous investigations, which reported up to $19.1 \mathrm{~g} / \mathrm{kg}$ of DM (Kalač and Pivničkova, 1987; Weiss et al., 2009a, 2015; Kristensen et al., 2010). The highest concentration of n-propanol was detected in a corn silage that had solely received heterofermentative $\mathrm{LAB}$, but also one untreated silage contained this substance, which support findings by Hafner et al. (2014). Although n-propanol represents a typical minor endproduct of anaerobic metabolism by yeasts (McDonald et al., 1991), it can also be formed by Lactobacillus diolivorans in conjunction with propionic acid via conversion of 1,2-propanediol (Krooneman et al., 2002). This, again, highlights the importance of the presence, prevalence, and abundance of certain microbial communities in silages on the production of certain fermentation products.

The concentration of ethyl lactate in the farm silages was higher than that of ethyl acetate, thereby confirming previous results (Weiss et al., 2009a). Apparently, untreated silages and those that had received homofermentative inoculants contained similar quantities of ethyl lactate, as also shown in our ensiling experiment 3 , but they had more than any other treated silages in the farm survey. Concentrations of ethyl acetate in our farm survey were very similar to results by Weiss et al. (2015), but about 10 times lower than the values reported by Raun and Kristensen (2010). Moreover, sampling site in farm silos may also play a role with regard to the concentrations of fermentation end-products (Borreani and Tabacco, 2010; Weiss et al., 2015) and the esters produced from them (Weiss et al., 2015), which confirms empirical observations on farms (Weiss et al., 2009a). The differences between sampling sites may be explained by usually lower $\mathrm{pH}$ in the lower, more compacted (Muck and Pitt, 1994), and less airaffected zones in farm silos as esterification processes were stimulated by low pH (Hangx et al., 2001; Weiss and Auerbach, 2013).

\section{Effects of Oxygen on Fermentation Pattern, Yeast Count, and Aerobic Stability}

The effect of oxygen by delayed sealing was tested in all 3 trials and showed large variation depending on the tested factors. When only silages that did not receive additive treatment were considered, consistently lower lactate contents by delayed sealing in our studies confirmed previous results in different silage types (Ruxton et al., 1975; Bolsen et al., 1993; Kim and Adesogan, 2006). 


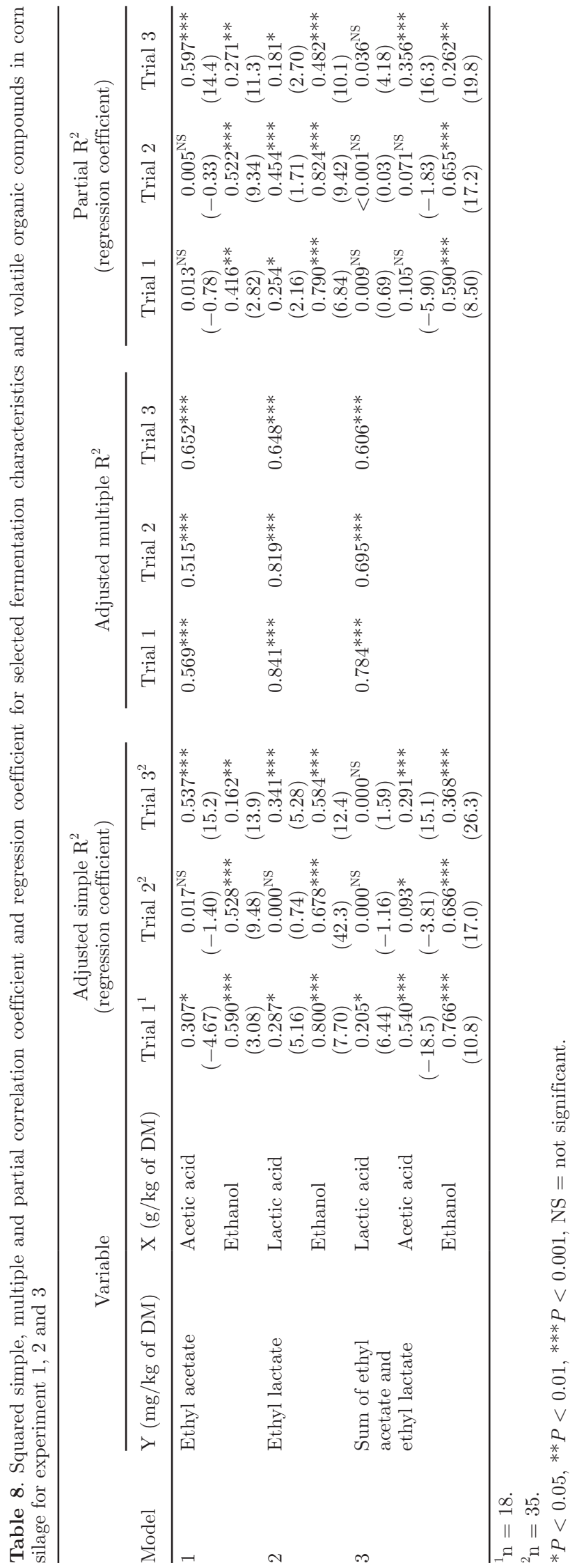

This may be attributed to prolonged respiration processes by plant enzymes or several epiphytic aerobic microorganisms competing with lactic acid bacteria for fermentable carbohydrates (McDonald et al., 1991; Pahlow et al., 2003). A stimulation of acetic acid formation by delayed sealing (Mills and Kung, 2002) was only observed in experiment 3 , whereas in experiments 1 and 2 , in which the same crop was used for silage preparation, this effect was not found. The inconsistency of effects of delayed sealing on acetate production may be associated with differences in the composition of the epiphytic microbial populations. Although heterofermentative lactic acid bacteria normally represent a significant portion of the total lactic acid bacteria community on fresh corn at harvest (Lin et al., 1992), they may not always be competitive to dominate the fermentation process. Moreover, air-associated alterations of sugar metabolism of certain lactic acid bacteria (Condon, 1987) or the activity of other major facultatively anaerobic acetate producers, such as enterobacteria, which normally die-off soon after anaerobiosis and low pH, have been attained (Pahlow et al., 2003) and may have contributed to different results.

Whereas delayed sealing had no effect on ethanol production in our experiments, it consistently reduced the concentrations of $n$-propanol in untreated silages when found in experiments 1 and 2. This finding cannot be discussed in relation with other published data as, to the best of our knowledge, this is the first time that this factor was tested in this regard. According to McDonald et al. (1991), Krooneman et al. (2002) and Amin et al. (2013), n-propanol can be produced by different microbial populations, including yeasts and certain lactic acid bacteria. Thus, delayed sealing may have affected, directly or indirectly, the metabolic activity of potential n-propanol producers. In our experiments, sealing time had variable effects on count of yeasts and aerobic stability. The enhanced aerobic stability by delayed sealing in experiment 3 supports data by Mills and Kung (2002) and can be explained by lower yeast counts and higher contents of acetic acid (Tabacco et al., 2011; Auerbach and Nadeau, 2013). Strong correlations have been observed between the concentrations of antimycotic acetate and the count of yeasts (Kleinschmit and Kung, 2006) and aerobic stability (Auerbach and Nadeau, 2013, Auerbach et al., 2013). The cause for the occasionally observed impaired aerobic stability despite lower yeast counts may have been the activity of acetic acid bacteria, which can also initiate aerobic spoilage of corn silage by oxidizing ethanol to acetic acid (Spoelstra et al., 1988; Muck and Pitt, 1994), but this microbial population was not analyzed in our studies. 
The effect of oxygen by repeated air ingress in comparison with no air ingress during the fermentation process was only tested in experiment 3 , as in experiment 2 all jars were aerated at regular intervals. Our results showed no effect of air ingress on lactic acid production, whereas McEniry et al. (2007) reported a depression. Air infiltration did not alter ethanol and acetic acid contents in the trials of McEniry et al. (2007), but we observed a stimulation of acetate formation in untreated silage sealed with delay and an increased ethanol production in promptly sealed silages.

Aeration did not affect aerobic stability in our studies, but McEniry et al. (2007) found slightly lower stability and a faster rise in temperature. The apparent discrepancies in fermentation pattern and aerobic stability can be attributed to differences in the aeration pattern. In our study, air was allowed to penetrate for the first time after $28 \mathrm{~d}$ of anaerobic storage and thereafter several times during fermentation for only $24 \mathrm{~h}$, whereas silages produced by McEniry et al. (2007) were continuously subjected to air ingress over the entire storage period of $100 \mathrm{~d}$. Unfortunately, additional studies on the effects of air infiltration on the fermentation process and aerobic stability are not available. Finally, large variations in the time elapsed to reach anaerobiosis and interactions between various factors, which were generally not tested, on the fermentation pattern, yeast count, and aerobic stability may be responsible for the observed differences between studies reflecting the complexity of the silage fermentation process and the inhabitant microbial ecosystem.

\section{Effects of Temperature on Fermentation Pattern, Yeast Count, and Aerobic Stability}

Storage temperature, which was tested in experiment 2 only, affected fermentation characteristics significantly. The results on reduced lactate production in silages that had not received additive treatment agreed with previous findings by Weinberg et al. (2001) and Kim and Adesogan (2006). Acetate and ethanol concentrations were highly variable in our study. The reasons for these observations remain unclear, but differences in the activities of certain microbial populations forming these metabolic end products appear most likely to be causal as well as the detected interactions of storage temperature with other tested factors. For example, optimum temperature for growth of enterobacteria representing another important group of acetate producers is higher than those for most epiphytic lactic acid bacteria (Pahlow et al., 2003). The increased npropanol concentrations in hot environments at silo opening cannot be conclusively explained by the activ- ity of yeasts, which are considered the most prominent microbial populations forming this substance. If they had produced n-propanol, then they likely synthesized this compound in the earlier stages of fermentation and died-off at later stages because the yeast count was below the detection limit at the end of silage storage. It may also be possible that certain bacteria (e.g., enterobacteria with a higher temperature optimum) contributed to n-propanol formation.

The results on lower yeast count associated with higher aerobic stability in promptly sealed silages by storage at higher temperatures before exposure to air substantiated observations by Kim and Adesogan (2006), although the magnitude of the effects was less pronounced when compared with our study. Moreover, the temperature used in the aerobic stability test may be responsible for differences, as Ashbell et al. (2002) showed that carbon dioxide production as an indicator for aerobic deterioration was more pronounced at $30^{\circ} \mathrm{C}$ than at 10,20 , or $40^{\circ} \mathrm{C}$, respectively.

\section{Effects of Silage Additives on Fermentation Pattern, Yeast Count, and Aerobic Stability}

Sodium benzoate-containing additives, which were used in all experiments, had variable but only minor effects on lactate and acetate levels of corn silages with no practical implications even at application rates of up to $2 \mathrm{~g} / \mathrm{kg}$ of fresh matter of active substance. This is in line with numerous studies using sodium benzoate or potassium sorbate alone (Bernardes et al., 2014; Da Silva et al., 2014; Hafner et al., 2014, 2015) or combinations thereof (Weiss and Auerbach, 2012b; Auerbach and Nadeau, 2013; Nadeau et al., 2015). In those studies and in our experiment 3 , consistently lower ethanol concentrations were detected, reflecting the strong inhibitory effect of sodium benzoate and potassium sorbate on yeasts as the main producers of silage alcohols, which is higher than that of propionate (Woolford, 1975). On the contrary, we observed no effect of the benzoate and propionate mixture in experiments 1 and 2 , which is likely explained by the comparatively low ethanol content of less than $8 \mathrm{~g} / \mathrm{kg}$ of DM, of which some may have been formed by other microorganisms, such as heterofermentative lactic acid bacteria. According to Woolford (1975), these microorganisms are less susceptible to sodium benzoate and potassium sorbate than fungi. It should be stressed here that the application rate of antimycotic substances is crucially important to have a pronounced antifungal effect (Auerbach and Nadeau, 2013), and that subinhibitory levels may even stimulate the activity of certain microbial populations resulting in larger ethanol production (Hafner et al., 
2014). This may also be the reason for the inconsistent effects of the antimycotic substances used in our studies on yeast counts and aerobic stability.

We found variable effects of the formic acid-based additives on lactic acid production confirming previous results (Weiss and Auerbach, 2012b; H. Auerbach and K. Weiss, unpublished data). However, the use of this additive type in our studies frequently suppressed acetic acid production and increased ethanol formation, which supports earlier results (Driehuis and van Wikselaar, 1996; Weiss and Auerbach, 2012b); this effect may be of general nature in corn silage, but it is usually not seen in grass silages (Randby, 2000; Weiss and Auerbach, 2015). Although lactic acid bacteria are less tolerant against formates than yeasts (Henderson et al., 1972), this effect must have been more pronounced on the heterofermentative populations as lactate levels remained largely unaffected, or the presence of formate may have altered metabolic pathways.

As the count of yeasts were low and often below the limit of detection upon use of the formic acid-based additives in our studies, it is postulated that over-proportional growth and ethanol formation had occurred during the early stages of fermentation. This hypothesis is supported by data by Middelhoven and van Baalen (1988), who reported a decline of the yeast population with progressing storage length after an increase during the initial stages of fermentation. Schmidt and Kung (2010) detected much lower yeast counts in corn silage after $120 \mathrm{~d}$ of fermentation when compared with those of the fresh forage from 5 different locations at ensiling. According to Weiss et al. (2009b), a very high proportion of the maximum ethanol content (77\%) was produced within the first month of fermentation. This would also explain why aerobic stability by formic acidbased additives is usually higher than that of untreated silages after prolonged storage periods (Driehuis and van Wikselaar, 1996; Weiss and Auerbach, 2012b; H. Auerbach and K. Weiss, unpublished data). The lower concentration of n-propanol by the formic acid-based additives might have been caused by the inhibition of bacteria, which can anaerobically convert 1,2-propanediol to n-propanol and other compounds (Krooneman et al., 2002; Amin et al., 2013).

As reported previously, there were no unequivocal effects of added homofermentative lactic acid bacteria on the formation of organic acids and ethanol (Kleinschmit et al., 2005; Filya and Sucu, 2010; Hafner et al., 2014). Normally, at the time of ensiling, fresh corn has a high number of epiphytic lactic acid bacteria (Lin et al., 1992), making it unlikely for added homofermentative inoculants to outperform them, especially if they were applied at typical inoculation rates of 100,000 $\mathrm{cfu} / \mathrm{g}$ of forage as in our study. The count of yeasts and aerobic stability were not influenced by lactic acid bacteria treatment, confirming results by Kleinschmit et al. (2005) and Queiroz et al. (2013). On the contrary, other studies showed negative effects on aerobic stability by inducing a more homolactic fermentation at the expense of acetic acid (Weinberg et al., 1998; Filya and Sucu, 2010).

\section{Effects of Oxygen, Temperature, and Silage Additives on the Formation of Ethyl Ester}

To the best of our knowledge, data on the influence of air and temperature on ester production in silage has not been published, making it impossible to discuss the effect of these factors individually. However, numerous studies have been performed demonstrating the effects of silage additives.

Previously, the effect of additives on ethyl ester formation was shown to depend mainly on their effect on ethanol concentrations (Weiss and Auerbach, 2012b, 2015). Data from our experiments supported observations from corn and sorghum silages (Auerbach and Weiss, 2012; Weiss and Auerbach, 2012b; Hafner et al., $2014,2015)$ that ethanol concentrations were reduced by the addition of salts of benzoic, sorbic, and propionic acids, respectively; these were accompanied by lower ethyl ester levels and the effect was dose-dependent (Hafner et al., 2014). The stimulation of ethyl ester formation in corn silage by the formic acid-based additive substantiates findings by Weiss and Auerbach (2012b) and can be explained the increased ethanol accumulation.

Our findings on ethyl lactate and ethyl acetate in experiments 1 and 2 and on ethyl lactate in experiment 3 that ethyl ester formation was more strongly correlated with the concentrations of ethanol than with those of acetic and lactic acids have been reported previously (Weiss et al., 2009a,b; Obitsu et al., 2014), highlighting the prominent role of the alcohol in ester formation. This is in agreement with Hafner et al. (2014), who showed a larger slope for ethanol and methanol than for acetic acid in their least square regression analysis on ethyl and methyl acetate. Likewise, for propyl acetate, stronger correlations were found between n-propanol and propyl acetate than between acetic acid and propyl acetate $\left(\mathrm{R}^{2}=0.77\right.$ vs. 0.58 , Raun and Kristensen, 2010; $\mathrm{R}^{2}=0.96$ vs. 0.74 , Kristensen et al., 2010). However, in our experiment 3, acetic acid had a larger influence on ester formation than was found for ethanol, thereby supporting data by Raun and Kristensen (2010). The reasons for this observation remain to be elucidated. It may be possible that the concentration of each reac- 
tion partner and its variation may have had an effect on the degree of correlation. Finally, the number of factors tested may play an important role regarding the strength of the relationship between ester-forming compounds because of likely interactions and interdependencies between them. In our study, up to 3 factors were used, whereas Weiss and Auerbach (2012b) and Hafner et al. (2014) only tested one factor, silage additive, and determined much stronger correlations between ethanol and esters $\left(R^{2}=0.99\right.$ and $R^{2}=0.96$, respectively).

\section{Origin of Ethyl Esters, Methodological Considerations, and Practical Implications}

Esters can be formed by abiotic esterification processes, which are stimulated by low $\mathrm{pH}$ (Weiss et al., 2009a; Raun and Kristensen, 2010; Weiss and Auerbach, 2013), or directly produced by lactic acid bacteria expressing the required enzymes for this reaction (Liu and Siezen, 2006). Moreover, certain yeast species, which also occur in silages (Pahlow et al., 2003), are capable of forming esters (Nordström, 1966; Fredlund et al., 2004). Thus, it seems very likely that both chemical and biochemical processes are involved.

The variability in ester concentrations among studies may have been caused by employing different detection methods. In our studies, we used aqueous extraction of esters coupled with GC, but others used headspace GC (Hafner et al., 2014, 2015). Especially for farm silages, sample collection may be crucial. For example, Hafner et al. (2010) showed that emissions of VOC from loose silage piles were higher than those from packed material due to differences in porosity, which, in turn, could result in higher concentrations when samples were taken from compacted silages. Weiss et al. (2011) reported no change in ester concentrations for $2 \mathrm{~d}$ of storage in loose piles when compared with the time of silo opening, but a decline thereafter. In addition, storage of the silage samples between collection and analysis warrants further attention. In our studies, silages were kept frozen until extraction for ester determination, which restricted microbial activity associated with potential changes in VOC profile, to the lowest achievable minimum. On the contrary, vacuum-packed samples were stored by Gerlach et al. (2013) at room temperature and by Hafner et al. (2014) at room temperature during the first week of storage and thereafter under refrigeration at about $4^{\circ} \mathrm{C}$. Storage of aqueous silage extracts in the freezer at $-18^{\circ} \mathrm{C}$ over several weeks is possible without affecting ester stability and can therefore be recommended (Weiss and Sommer, 2012). As ester analysis is a time- consuming, costly procedure and requires specialized laboratory equipment, the first modeling attempts have been made to predict the levels of ethyl esters based on the concentration of routinely measured ethanol. Weiss and Auerbach (2012a) proposed a simple linear regression model using a total of 524 laboratory corn, wheat, sorghum, and grass silages, as well as 14 corn silages from dairy farms. Each incremental increase in ethanol by $5 \mathrm{~g} / \mathrm{kg}$ of DM increased total ethyl ester concentration by about $100 \mathrm{mg} / \mathrm{kg}$ of DM ( $\mathrm{y}=102.8 \mathrm{x}$, $\left.\mathrm{R}^{2}=0.90\right)$.

The inclusion of additional 608 data sets from grass, a total of 1,146 data sets (Weiss and Auerbach, 2013), had no marked effect on the linear equation $(\mathrm{y}=114 \mathrm{x})$ compared with the previous model, although it reduced the correlation coefficient $\left(\mathrm{R}^{2}=0.76\right)$. However, for practical applications it is still sufficiently precise to be used as a tool for rapid and preliminary evaluation of ester content. Further investigations are encouraged to broaden the database also by using data from other silage types (e.g., sugar cane) with known high content of ethanol (Daniel et al., 2013b) and other volatile compounds.

\section{CONCLUSIONS}

Delayed sealing, repeated air infiltration during anaerobic storage, temperature, and additive use largely affected fermentation pattern, yeast count, and aerobic stability of corn silage in a nondirectional manner. The detected numerous interactions between individual factors reflect the complexity of the silage ecosystem. Thus, it seems unlikely that it will ever be possible to precisely predict the outcome of silage fermentations. The production of ethyl esters of lactic acid and, to a lesser extent, of acetic acids was correlated with the concentration of ethanol highlighting the prominent role of the alcohol in the formation of esters in silage. Therefore, any measure that reduces ethanol accumulation will restrict ester formation. Salts of sorbic, benzoic, or propionic acids or mixtures thereof applied at sufficient quantities appear to be the most promising additives to control VOC production in corn silage, whereas formic acid-based additives and homofermentative inoculants do not have this potential.

\section{ACKNOWLEDGMENTS}

We acknowledge the expert technical support by the staff of the Common Laboratory of Analysis, Humboldt Universität zu Berlin, especially Gabriele Sommer and by Manuela Alt for performing GC and HPLC 
analyses. We thank Christine Kalzendorf, Chamber of Agriculture Lower-Saxony, Germany, for conducting the ensiling experiments and ADDCON GbmH, Bonn, Germany, for partial funding of the studies. The comments by the reviewers on the manuscript are greatly appreciated and contributed to improving its quality.

\section{REFERENCES}

Adam, L., W. Bartels, and N. Christoph. 1995. Untersuchungen von Destillaten und Bränden. Brennereianalytik 2:27-39. (Analysis of distillates and brandies).

Amin, H. M., A. M. Hashem, M. S. Ashour, and R. Hatti-Kaul. 2013. 1,2 propanediol utilization by Lactobacillus reuteri DSM 20016, role in bioconversion of glycerol to 1,3 propanediol, 3-hydroxypropionaldehyde and 3-hydroxypropionic acid. J. Genet. Engin. Biotechnol. 11:53-59.

Ashbell, G., Z. G. Weinberg, Y. Hen, and I. Filya. 2002. The effects of temperature on the aerobic stability of wheat and corn silages. J. Ind. Microbiol. Biotechnol. 28:261-263.

Auerbach, H., and E. Nadeau. 2013. Effects of chemical additives on whole crop maize silage traits. Pages $736-737$ in Proc. 22 Int. Grassl. Congr., Sydney, New South Wales, Australia. D. L. Michalk, G. D. Millar, W. B. Badgery, and K. M. Broadfoot, ed. New South Wales Department of Primary Industry, Orange, New South Wales Australia.

Auerbach, H., and K. Weiss. 2012. The effect of different types of silage additives on dry matter losses, fermentation pattern, volatile organic compounds and aerobic stability of sorghum silage. Pages 418-419 in Proc. XXI Int. Silage Conf., Hämeenlinna, Finland. K. Kuoppala, M. Rinne, and A. Vanhatalo, ed. MTT Agrifood Research Finland, Universiy of Helsinki, Helsinki, Finland.

Auerbach, H., K. Weiss, and E. Nadeau. 2012. Benefits of using silage additives. Pages 75-144 in Proc. 1 Int. Silage Summit, Leipzig, Saxony, Germany. H. Auerbach, C. Lückstädt, and F. Weissbach, ed. Anytime Publishing Services, Worthington, UK.

Auerbach, H., K. Weiss, P. Theobald, and E. Nadeau. 2013. Effect of inoculant type on dry matter losses, fermentation pattern, yeast count and aerobic stability of green rye silages. Pages 179-185 in Proc. 12 BOKU Symposium Tiernerährung, Vienna, Austria. C. Mair, M. Kraft, and K. Schedle, ed. Universität für Bodenkultur, Vienna, Austria.

Bernardes, T. F., I. L. De Oliviera, M. A. S. Lara, D. R. Casagrande, C. L. S. Avila, and O. G. Pereira. 2014. Effects of potassium sorbate and sodium benzoate at two application rates on fermentation and aerobic stability of maize silage. Grass Forage Sci. 70:491-498. http://dx.doi.org/10.1111/gfs.12133.

Bolsen, K. K., J. T. Dickerson, B. E. Brent Jr., R. N. Sonon, B. S. Dalke, C. Lin, and J. E. Boyer. 1993. Rate and extent of top spoilage losses in horizontal silos. J. Dairy Sci. 76:2940-2962.

Borreani, G., and E. Tabacco. 2010. The relationship of silage temperature with the microbiological status of the face of corn silage bunkers. J. Dairy Sci. 93:2620-2629.

Condon, S. 1987. Responses of lactic acid bacteria to oxygen. FEMS Microbiol. Lett. 46:269-280.

Da Silva, N. C., J. P. Dos Santos, C. L. S. Avila, A. R. Evangelista, D. R. Casagrande, and T. F. Bernardes. 2014. Evaluation of the effects of two Lactobacillus buchneri strains and sodium benzoate on the characteristics of corn silage in a hot-climate environment. Grassl. Sci. 60:169-177.

Daniel, J. L. P., R. C. Amaral, R. S. Goulart, M. Zopolatto, V. P. Santos, S. G. Toledo Filho, E. H. Cabezas-Garcia, J. R. Lima, M. C. Santos, and L. G. Nussio. 2013c. Short-term effects of silage volatile compounds on feed intake and digestion of beef cattle. J. Anim. Sci. 91:2321-2331.

Daniel, J. L. P., R. C. Amaral, A. Sá Neto, E. H. Cabezas-Garcia, A. W. Bispo, M. Zopollatto, T. L. Cardoso, M. H. F. Spoto, F. A. P.
Santos, and L. G. Nussio. 2013a. Performance of dairy cows fed high levels of acetic acid or ethanol. J. Dairy Sci. 96:398-406.

Daniel, J. L. P., K. Weiss, L. Custódio, A. Sá Neto, M. C. Santos, M. Zopollatto, and L. G. Nussio. 2013b. Occurrence of volatile organic compounds in sugarcane silages. Anim. Feed Sci. Technol. 185:101-105.

Driehuis, F., and P. G. van Wikselaar. 1996. Effects of addition of formic, acetic, or propionic acid to maize silage and low dry matter grass silage on the microbial flora and aerobic stability. Pages 256-257 in Proc. XI Int. Silage Conf., Aberystwyth, Wales. D. I. H. Jones, R. Dewhurst, R. Merry, and P. M. Haigh. ed. University of Wales, Aberystwyth, Wales, UK.

Filya, I., and E. Sucu. 2010. The effects of lactic acid bacteria on the fermentation, aerobic stability and nutritive value of maize silage. Grass Forage Sci. 65:446-455.

Fredlund, E., U. Ä. Druvefors, M. N. Olstorpe, V. Passoth, and J. Schnürer. 2004. Influence of ethyl acetate production and ploidy on the anti-mould activity of Pichia anomala. FEMS Microbiol. Lett. 238:133-137.

Gerlach, G., F. Ross, K. Weiss, W. Büscher, and K.-H. Südekum. 2013. Changes in maize silage fermentation products during aerobic deterioration and effects on dry matter intake by goats. Agric. Food Sci. 22:168-181.

Hafner, S. D., R. B. Franco, L. Kung Jr., C. A. Rotz, and F. Mitloehner. 2014. Potassium sorbate reduces production of ethanol and 2 esters in corn silage. J. Dairy Sci. 97:7870-7878.

Hafner, S. D.. C. R. Howard, R. E. Muck, B. Franco, F. Montes, P. G. Green, F. Mitloehner, S. L. Trabue, and C. A. Rotz. 2013. Emission of volatile organic compounds from silage: Compounds, sources, and implications. Atmos. Environ. 77:827-839.

Hafner, S. D., F. Montes, and C. A. Rotz. 2012. A mass transfer model for VOC emission from silage. Atmos. Environ. 54:134-140.

Hafner, S. D., F. Montes, C. A. Rotz, and F. Mitloehner. 2010. Ethanol emission from loose corn silage and exposed silage particles. Atmos. Environ. 44:4172-4180.

Hafner, S. D., M. Windle, C. C. Merrill, M. L. Smith, R. B. Franco, and L. Kung Jr. 2015. Effects of potassium sorbate and Lactobacillus plantarum MTD1 on production of ethanol and other volatile organic compounds in corn silage. Anim. Feed Sci. Technol. 208:79-85. http://dx.doi.org/10.1016/j.anifeedsci.2015.07.007.

Hangx, G., G. Kwant, H. Maessen, P. Markusse and I. Urseanu. 2001. Reaction kinetics of the esterification of ethanol and acetic acid towards ethyl acetate. Deliverable 22, workpackage 6 , technical report. Intelligent column internals for reactive separations (INTINT), project no GRD1 CT199910596. European Industrial Research magazine. European Commission, Research DG, Directorate G (Industrial Technologies). ESN, Brussels, Belgium.

Henderson, A. R., P. McDonald, and M. K. Woolford. 1972. Chemical changes and losses during the ensilage of wilted grass treated with formic acid. J. Sci. Food Agric. 23:1079-1087.

Honig, H. 1990. Evaluation of aerobic stability. Pages 76-82 in Proc. Eurobac Conf., 12-16 August 1986, Uppsala, Sweden. Grovfoder, Grass and Forage Reports, Swedish University of Agricultural Sciences, Special Issue, 3.

Howard, C. J., A. Kumar, I. Malkina, F. Mitloehner, P. G. Green, R. G. Flocchini, and M. J. Kleeman. 2010. Reactive organic gas emissions from livestock feed contribute significantly to ozone production in central California. Environ. Sci. Technol. 44:2309-2314.

Jonsson, A., and G. Pahlow. 1984. Systematic classification and biochemical characterization of yeasts growing in grass silages inoculated with Lactobacillus cultures. Anim. Res. Dev. 20:7-11.

Kalač, P., and L. Pivničkova. 1987. Evaluation of the occurence of lower alcohols in haylage and silage. Zivocisna Vyroba 32:641-645.

Kim, S. C., and A. T. Adesogan. 2006. Influence of ensiling temperature, simulated rainfall, and delayed sealing on fermentation characteristics and aerobic stability of corn silage. J. Dairy Sci. 89:3122-3132.

Kleinschmit, D. H., and L. Kung Jr. 2006. A meta-analysis on the effects of Lactobacillus buchneri on the fermentation and aerobic 
stability of corn and grass and small-grain silages. J. Dairy Sci. 89:4005-4013.

Kleinschmit, D. H., R. J. Schmidt, and L. Kung Jr. 2005. The effects of various antifungal additives on the fermentation and aerobic stability of corn silage. J. Dairy Sci. 88:2130-2139.

Kleinshmitt, C., G. Morais, L. Custodio, F. Fernandez, M. C. Santos, J. L. P. Daniel, and L. G. Nussio. 2013. Performance of lactating dairy cows fed maize silage with increased dosages of $L$. buchneri Pages 141-142 in Proc. XV Int. Conf. Forage Conserv., High Tatras, Slovak Republic. L. Rajcakova, ed. Animal Production Centre, Nitra, Slovak Republic, Slovak University of Agriculture Nitra, Slovak Republic, NutriVet Ltd., Pohorelice, Czech Republic.

Kristensen, N. B., K. Sloth, O. Hjberg, N. Spliid, C. Jensen, and R. Thogersen. 2010. Effects of microbial inoculants on corn silage fermentation, microbial contents, aerobic stability, and milk production under field conditions. J. Dairy Sci. 93:3764-3774.

Krizsan, S. J., F. Westad, T. Adnoy, E. Odden, S. E. Aakre, and A. T. Randby. 2007. Effect of volatile compounds in grass silage on voluntary intake by growing cattle. Animal 1:283-292.

Krooneman, J., F. Faber, A. C. Alderkamp, S. J. H. W. Oude Elfering, F. Driehuis, L. Cleenwerck, J. Swings, J. C. Gottschal, and M. Vancanneyt. 2002. Lactobacillus diolivorans sp. nov., a 1,2-propanediol-degrading bacterium isolated from aerobically stable maize silage. Int. J. Syst. Evol. Microbiol. 52:639-646.

Kung, L., Jr., and R. D. Shaver. 2001. Interpretation and use of silage fermentation analysis reports. Focus on Forage. Vol. 3: No.13. University of Wisconsin Extension, Madison. Accessed Apr. 12, 2016. http://fyi.uwex.edu/forage/files/2014/01/Fermentation.pdf.

Kung, L., M. R. Stokes, and C. J. Lin. 2003. Silage additives. Pages 305-360 in Silage Science and Technology. D. R. Buxton, R. E Muck, and R. E. Harrison, ed. American Society of Agronomy Inc., Crop Science Society of America Inc., Soil Science Society of America Inc., Madison, WI.

Lin, C., K. K. Bolsen, B. E. Brent, and D. Y. C. Fung. 1992. Epiphytic lactic acid bacteria succession during pre-ensiling and ensiling periods of alfalfa and maize. J. Appl. Microbiol. 73:375-387.

Littell, R. C., G. A. Milliken, W. W. Stroup, R. D. Wolfinger, and O. Schabenberger. 2006. SAS for Mixed Models. 2nd ed. SAS Inst., Cary, NC.

Liu, M., and R. Siezen. 2006. Comparative genomics of flavour-forming pathways in lactic acid bacteria. Aust. J. Dairy Technol. 61:61-68.

Malkina, I. L., A. Kumar, P. G. Green, and F. M. Mitloehner. 2011 Identification and quantitation of volatile organic compounds emitted from dairy silages and other feedstuffs. J. Environ. Qual. 40:28-36.

Mari, L. J., R. J. Schmidt, L. G. Nussio, C. M. Hallada, and L. Kung Jr. 2009. An evaluation of the effectiveness of Lactobacillus buchneri 40788 to alter fermentation and improve the aerobic stability of corn silage in farm silos. J. Dairy Sci. 92:1174-1176.

McDonald, P., A. R. Henderson, and S. J. E. Heron. 1991. The Biochemistry of Silage. 2nd ed. Chalcombe Puplications, Marlow, UK.

McEniry, J., P. O'Kiely, N. J. W. Clipson, P. D. Forristal, and E. M. Doyle. 2007. The relative impacts of wilting, chopping, compaction and air infiltration on the conservation characteristics of ensiled grass. Grass Forage Sci. 62:470-484.

Middelhoven, W. J., and A. H. M. van Baalen. 1988. Development of the yeast flora of whole crop maize during ensiling and during subsequent aerobiosis. J. Sci. Food Agric. 42:199-207.

Mills, J. A., and L. Kung Jr. 2002. The effect of delayed ensiling and application of a propionic acid-based additive on the fermentation of barley silage. J. Dairy Sci. 85:1969-1975.

Morgan, M. E., and R. L. Pereira. 1962. Volatile constituents of grass and corn silages. II Gas entrained aroma. J. Dairy Sci. 45:467-471.

Moshtaghi Nia, S. A., and K. M. Wittenberg. 2000. Effect of delayed wrapping on preservation and quality of whole crop barley forage ensiled as large bales. Can. J. Anim. Sci. 80:145-151.

Muck, R. E., and R. E. Pitt. 1994. Aerobic deterioration in corn silage relative to the silo face. Trans. ASAE 37:735-743.

Nadeau, E., A. Arnesson, J. Jakobsson, and H. Auerbach. 2015. Chemical additives reduce yeast count and enhance aerobic stability in high dry matter corn silage. Pages 353- 355 in Proc. XVII Int.
Silage Conf., Piracicaba, Sao Paulo, Brazil. J. L. P. Daniel, G. Morais, D. Junges, and L. G. Nussio, ed. University of Sao Paulo, Piracicaba, SP, Brazil.

Nordström, K. 1966. Formation of esters from lower chain fatty acids by various yeast species. J. Inst. Brew. 72:38-40.

Obitsu, T., K. Hosoba, T. Sugino, K. Taniguchi, A. Astuti and M. El-Sabagh. 2014. Variation of alcohol and ester contents in round bale silage of grass and whole crops. Pages 1788-1791 in Proc. 16th AAAP Congr., Vol. II. Gadja Mada University, Yogyakarta, Indonesia. Asian-Australasian Associations of Animal Production Societies, ed. Seoul, Korea.

Oude-Elferink, S. J., J. Krooneman, J. C. Gottschal, S. F. Spoelstra, F. Faber, and F. Driehuis. 2001. Anaerobic conversion of lactic acid to acetic acid and 1,2-propanediol by Lactobacillus buchneri. Appl. Environ. Microbiol. 67:125-132.

Pahlow, G., R. E. Muck, F. Driehuis, S. J. W. H. Oude Elferink, and S. F. Spoelstra. 2003. Microbiology of ensiling. Pages 31-93 in Silage science and technology. D. R. Buxton, R. E. Muck, and R. E. Harrison, ed. American Society of Agronomy Inc., Crop Science Society of America Inc., Soil Science Society of America Inc., Madison, WI

Queiroz, O. C. M., K. G. Arriola, J. L. P. Daniel, and A. T. Adesogan. 2013. Effects of 8 chemical and bacterial additives on the quality of corn silage. J. Dairy Sci. 96:5836-5843.

Randby, A. 2000. The effect of some acid-based additives applied to wet grass crops under various ensiling conditions. Grass Forage Sci. 55:289-299.

Randby, A. T., I. Selmer-Olsen, and L. Baevre. 1999. Effect of ethanol in feed on milk flavor and chemical composition. J. Dairy Sci. $82: 420-428$.

Ranjit, N. K., C. C. Neylor, and L. Kung Jr. 2002. Effect of Lactobacillus buchneri 40788 on the fermentation, aerobic stability and nutritive value of maize silage. Grass Forage Sci. 57:73-81.

Raun, B. M. L., and N. B. Kristensen. 2010. N-propanol in maize silage at Danish dairy farms. Acta Agric. Scand. A 60:53-61.

Ruxton, I. B., B. J. Clark, and P. Macdonald. 1975. A review on the effects of oxygen on ensilage. J. Br. Grassl. Soc. 30:23-30.

Savage, R. M., M. C. Windle, S. D. Johannismeier, and L. Kung Jr. 2014. The effects of strains of yeasts or Lactobacillus buchneri 40788 on the fermentation, production of volatile organic compounds (VOCs) and aerobic stability of corn silage. J. Dairy Sci. 97(E-Suppl. 1):537-538.

Schabenberger, O., and F. J. Pierce. 2002. Contemporary Statistical Models for the Plant and Soil Sciences. CRC Press, Boca Raton, FL.

Schmidt, R. J., and L. Kung Jr. 2010. The effects of Lactobacillus buchneri with or without homolactic bacterium on the fermentation and aerobic stability of corn silages made at different locations. J. Dairy Sci. 93:1616-1624.

Spoelstra, S. F., M. G. Courtin, and J. A. C. van Beers. 1988. Acetic acid bacteria can initiate aerobic deterioration of whole crop maize silage. J. Agric. Sci. 111:127-132.

Tabacco, E., S. Piano, A. Revello-Chion, and G. Borreani. 2011. Effect of Lactobacillus buchneri LN4637 and Lactobacillus buchneri LN40177 on the aerobic stability, fermentation products, and microbial populations of corn silage under farm conditions. J. Dairy Sci. 94:5589-5598.

Weinberg, Z. G., G. Szakacs, G. Ashbell, and Y. Hen. 1998. The effect of temperature and Lactobacillus amylovorus and Lact. plantarum, applied at ensiling, on wheat silage. J. Appl. Microbiol. 84: 404-408

Weinberg, Z. G., G. Szakacz, G. Ashbell, and Y. Hen. 2001. The effect of temperature on the ensiling process of corn and wheat. J. Appl Microbiol. 90:561-566.

Weiss, K. 2001. Gärungsverlauf und Gärqualität von Silagen aus nitratarmem Grünfutter. [Course of fermentation and fermentation quality of silages from low-nitrate crops]. Doctoral thesis. Faculty of Agricultural and Horticultural Science, Humboldt Universität zu Berlin, Berlin, Germany.

Weiss, K., and H. Auerbach. 2012a. Occurrence of volatile organic compounds and ethanol in different types of silages. Pages 128-129 
in Proc. XXI Int. Silage Conf., Hämeenlinna, Finland. K. Kuoppala, M. Rinne, and A. Vanhatalo, ed. MTT Agrifood Research Finland, Universiy of Helsinki, Helsinki, Finland.

Weiss, K., and H. Auerbach. 2012b: The effect of different types of chemical silage additives on DM losses, fermentation pattern, volatile organic compounds (VOC) and aerobic stability of maize silage. Pages 360-361 in Proc. XXI Int. Silage Conf., Hämeenlinna, Finland. K. Kuoppala, M. Rinne, and A. Vanhatalo, ed. MTT Agrifood Research Finland, University of Helsinki, Helsinki, Finland.

Weiss, K., and H. Auerbach. 2013. Volatile organic compounds (VOC) in grass silages. Pages 721-722 in Proc. 22 Internatl. Grassl. Congr., Sydney, New South Wales, Australia. D. L. Michalk, G. D. Millar, W. B. Badgery, and K. M. Broadfoot, ed. New South Wales Department of Primary Industry, Orange, New South Wales, Australia.

Weiss, K., and H. Auerbach. 2015. The influence of additives on fermentation pattern, volatile organic compounds (VOC) and aerobic stability of grass silage. Pages 396-397 in Proc. XVII Int. Silage Conf., Piracicaba, Sao Paulo, Brazil. J. L. P. Daniel, G. Morais, D. Junges, and L. G. Nussio, ed. University of Sao Paulo, Piracicaba, SP, Brazil.

Weiss, K., K. Gerlach, and K.-H. Südekum. 2011. Flüchtige Substanzen in Maissilagen in Abhängigkeit von Silierbedingungen und aerober Lagerungsdauer. VDLUFA-Schriftenreihe 67:534-540. (Volatile compounds in corn silages as affected by ensiling conditions and aerobic storage length).

Weiss, K., and E. Kaiser. 1995. Milchsäurebestimmung in Silageextrakten mit Hilfe der HPLC. Wirtsch. Futter 41:69-80. (Lactic acid determination in silage extracts by HPLC).

Weiss, K., C. Kalzendorf, J. Zittlau, and H. Auerbach. 2009a. Novel results on the occurrence of volatile compounds in maize silages.
Pages 339-340 in Proc. XV Int. Silage Conf., Madison, WI. G. A. Broderick, A. T., Adesogan, L. W. Bocher, K. K. Bolsen, F. E. Contreras-Govea, J. H. Harrison, and R. E. Muck, ed. US Dairy Forage Research Center, Madison, WI.

Weiss, K., C. Kalzendorf, J. Zittlau, and H. Auerbach. 2009b. Formation of volatile compounds during fermentation of forage maize. Pages 33-34 in Proc. XV Int. Silage Conf., Madison, WI. G. A. Broderick, A. T., Adesogan, L. W. Bocher, K. K. Bolsen, F. E. Contreras-Govea, J. H. Harrison, and R. E. Muck, ed. US Dairy Forage Research Center, Madison, WI.

Weiss, K. C. Olbrich, and J. Thaysen. 2015. Volatile organic compounds (VOC) in maize silages at German dairy farms. Pages 98-99 in Proc. XVII Int. Silage Conf., Piracicaba, Sao Paulo, Brazil. J. L. P. Daniel, G. Morais, D. Junges, and L. G. Nussio, ed. University of Sao Paulo, Piracicaba, SP, Brazil.

Weiss, K., and G. Sommer. 2012. Bestimmung von Estern und anderen flüchtigen organischen Substanzen (VOC) in Silageextrakten mit Hilfe der Gaschromatographie. VDLUFA-Schriftenreihe 68:561-569. (Determination of esters and other volatile organic compounds (VOC) in silage extracts by gas-chromatography).

Weissbach, F., and C. Strubelt. 2008. Correcting the dry matter content of maize silages as a substrate for biogas production. Landtechnik-Net 63:82-83. Accessed Jun. 19, 2016. https://www. landtechnik-online.eu/ojs-2.4.5/index.php/landtechnik/article/ view/2008-2-082-083/1237.

Woolford, M. K. 1975. Microbiological screening of food preservatives, cold sterilants an specific antimicrobial agents as potential silages additives. J. Sci. Food Agric. 26:229-237. 